\title{
Editorial
}

\section{Academic Freedom and (Anti) Social Media?}

In this the first issue of the 2022 year, it seems timely to address a topic that is uppermost in the rhetoric around high education - and at the center of my commitment to higher education: academic freedom.

My introduction to the concept of academic freedom was as a newbie librarian-and I did not realize at the time how privileged I was to attain a position that was a tenure-track faculty position at an institution with enough funding to support research and service. My focus then was on developing research skills and identifying a focus that was compelling to me and to others (although I must admit that my initial intention was to stay 3 years and then go back to the West Coast once I had some experience -25 years later, I am still in Texas).

My concept of academic freedom was formed from this experience-where I have the latitude (and responsibility) to choose my own direction for my research.

That said, academic freedom also has a place in the work we do-for teaching faculty, in the classroom: for librarians, how we interact with our patrons and engage with services and projects. There is some (LOTS!) difference of opinion on what academic freedom looks like in this setting - and I have heard faculty interpret it as "you can't tell me what to do." The fact that it has different meaning for different people (depending on their experience, priorities and roles) is an inevitable truth and a benefit - but the flexibility also allows for ambiguity and arbitrariness because of these completing interests. For my own understanding, I believe that an organization can tell faculty what to do-and, in fact, it needs to so that the priorities and mission of the university are being met. Academic freedom comes in as faculty may determine HOW to do their job - the approach, the methods, the engagement.

Academic freedom can be informed by a number of other factors - for example, if there is an institution or a state where labor is strong, collective bargaining has an impact on the reach of academic freedom and its protections.

One of the other interesting elements is academic freedom's intersection with intellectual freedom, a fundamental value for which libraries and librarians advocate. It is no doubt that both are under attack - and there is irony in that it is vehicles for free speech that are undermining it and the attacks are coming from both (or all?) sides.

The first inkling that the attacks on academic freedom went beyond the usual tensions was a situation that hit close to home, literally. Tommy Curry, a Philosophy Professor at Texas A\&M University, was encouraged to engage in the classroom and his research on race, to challenge the status quo and to promote critical thinking and dialogue. ${ }^{1}$ Whether one agrees with his methods or not, it is clear to me that he was exercising his academic freedom and that the response was neither academic nor thoughtful, but reactionary - on the part of the public and the university administration. It sent a strong message to the faculty at the institution that the University did not have the faculty's backs and that media (and social media) would determine how they were supported (or not). 
This is not to say that social media is bad-like any other mode, it is the author that determines the message (although, to quote McLuhan "the Medium is the Message"). Having worked with faculty in government and international affairs, social media can be a great equalizer as well as a tool for accountability - Arab Spring is one prime example of how social media promoted citizens to become activists and generated change (the Guardian ${ }^{2}$ created a compelling visualization on how social media spread the message across borders). The \#metoo movement is another such example, empowering those who had been victimized and shining light on a widespread societal problem, ultimately changing norms.

Tommy Curry's situation was not the first - and it was certainly not the last. The Foundation for Individual Rights in Education ${ }^{3}$ looks at policies regulating student expression and academic freedoms. Incidents of attacks via social media (including threats!) on faculty have steadily increased.

\section{FIRE reports of targeting incidents, as of $12 / 2 / 2021$}

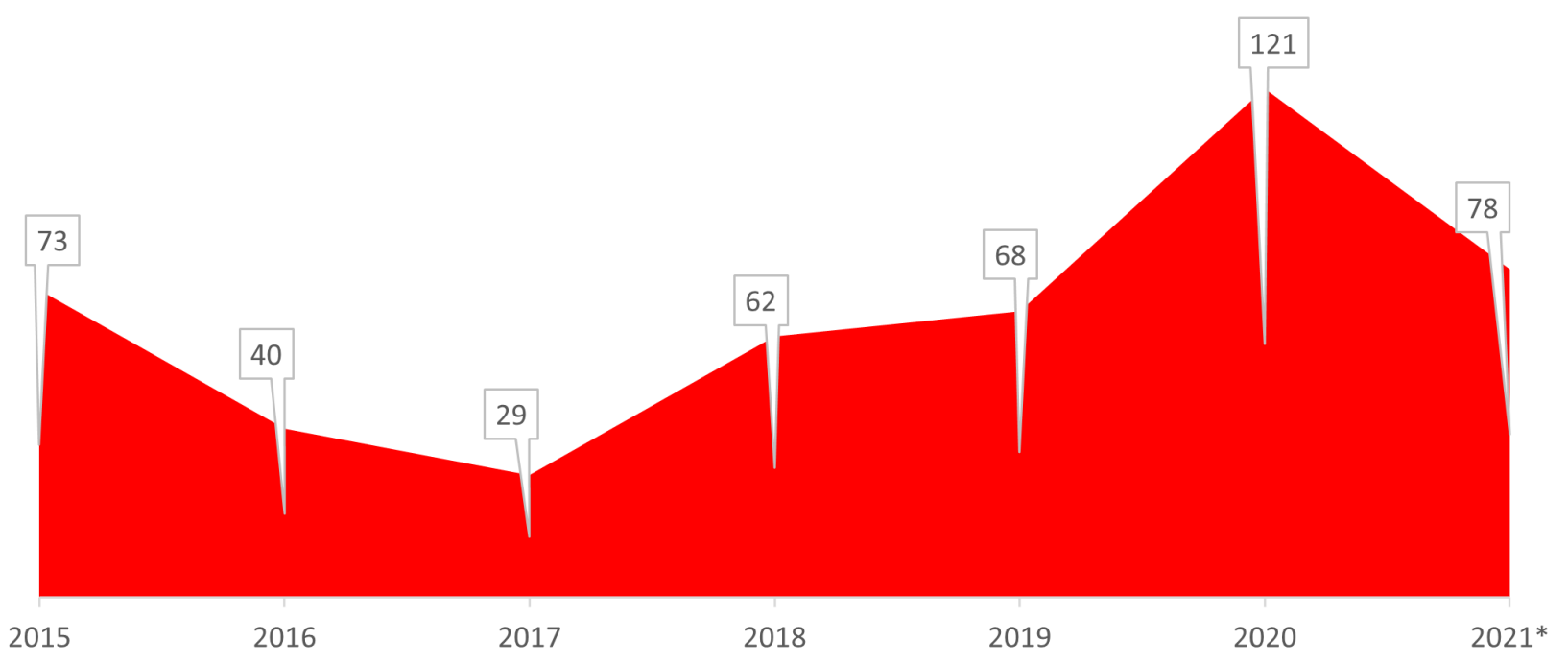

We have seen attacks from all sides (because, while politics are polarized, there are so many more viewpoints). The irony is that in one group's desire to protect their freedoms, many times they infringe on the freedoms of others who are not in their community or of likeminded perspectives. To be fair, 2021 is not ended yet-however, there has been a disturbing upward trend.

Most recently, there are the glaring examples of Florida ${ }^{4}$, North Carolina ${ }^{5}$ and Georgia ${ }^{6}$ where the governance boards and state legislatures have actively inserted themselves into not just what is taught but HOW faculty are engaging in the classroom, offering their expertise and contributing to public scholarship. There are policies ${ }^{7}$ and laws ${ }^{8}$ that seek to constrain how faculty exercise their academic freedoms.

For all the alarming circumstances that get reported, there are, periodically, times when an institution gets it right - and this brings hope. Syracuse University offered unequivocal support and condemned threats made against a professor who had made comments about September 11. ${ }^{9}$

Again, institutions with collective bargaining agreements or private institutions are under other constraints and policies - and are likely no better or worse but public institutions invite 
additional scrutiny, taxpayers, legislators and parents are all heavily invested in what public universities do. This is not too dissimilar from the scrutiny that public libraries face, in just the way that a taxpayer may feel the right to question the acquisition of materials in a public library (which they are in ever increasing numbers ${ }^{10}$ ). That defense of intellectual freedom is critical - "A truly great library contains something in it to offend everyone" (Jo Goodwin).

Public institutions do have a responsibility to their publics - and transparency is a best practice. That said, shared governance is also a best practice-and a foundational value of higher education. While shared governance varies a lot-in some cases, it is built into the institutional rules and policies (or collective bargaining) and in other cases, it is just a check box without any real meaning or consideration - the standard practice is that of an administrator giving a "preliminary" report, getting faculty feedback, and then doing what they were going to do anyway (my current institution is looking at sweeping changes that seem to just take cursory feedback from faculty which will be unlikely to change the outcomes). However, sometimes there is a higher power that gets involved to address certain standards and uphold shared governance-just as legislators seem to be pushing to minimize, accreditors are pushing back to uphold it. ${ }^{11}$

There is a purpose for academic freedom - knowledge can only move forward if it questions the status quo and pushes boundaries. This is true not just in our research and publication but in our practice and teaching - and, to be honest, these are qualities that I would hope we also want to instill in our students. Institutions of higher education should provide a space for learning, modelling best practice about scholarly dialogue, and dealing with controversial issues in a way that is open, respectful, and productive. Institutions can also promote studentled activism ${ }^{12}$ by working with student associations and learning communities centered on social/procedural justice and using design thinking to provide a framework.

\section{"How do you budget your integrity?"}

When I heard this, I thought it must be a philosopher or leader who said it-but I could not find this exact quote. It was actually a line from a recent episode of Blue Bloods - but it struck me as a critical (and somewhat disillusioning) question.

Academic freedom is for the benefit of the community - even when the community does not recognize or stand up for it. It is for the benefit of those currently in academia and for future scholars and students. It is not just for academics - it is for the public and the community, both local and global. Like many freedoms, it must be won not just once but over and over. It is something that advocates and practitioners (everyday librarians and teaching faculty) must stand up for and practice-it means asking the hard questions (in a professional way) and being prepared to take a stand. It is something that we have a responsibility to do-and it can be hard and it can take a lot of energy-but it is essential for advocates of academic, and intellectual freedom.

\section{Notes}

1. Steve Kolowich, "Tough Talk," July 26, 2017, The Chronicle of Higher Education, https://www.chronicle.com/ article/tough-talk/.

2. Michael Safi, Antonio Voce, Frank Hulley-Jones and Lydia McMullan, "How the Arab spring engulfed the Middle East-and changed the world," Monday 25 Jan 2021, The Guardian, https://www.theguardian.com/ 
world/ng-interactive/2021/jan/25/how-the-arab-spring-unfolded-a-visualisation.

3. Foundation For Individual Rights In Education (FIRE), https://www.thefire.org/.

4. Jeffrey C. Isaac, "Florida Is a Five-Alarm Fire for Academic Freedom," The Chronicle of Higher Education, October 31, 2021, https://www.chronicle.com/article/florida-is-a-five-alarm-fire-for-academic-freedom.

5. Keith E. Whittington and Sean Wilentz, "We Are Critics of Nikole Hannah-Jones. Her Tenure Denial Is a Travesty," May 24, 2021, The Chronicle of Higher Education, https://www.chronicle.com/article/we-have-criticizednikole-hannah-jones-her-tenure-denial-is-a-travesty.

6. Colleen Flaherty, "Tenure Under Threat in Georgia," Inside Higher Ed, October 4, 2021, https://www.insidehighered.com/news/2021/10/04/tenure-under-threat-georgia.

7. The Texas A\&M University System, "Employee Use \& Engagement Guidelines," https://www.tamus.edu/ marcomm/socialmedia/employee-guidelines/.

8. Len Gutkin, "The Review: From Georgia to Michigan to Yale, Tenure and Self-Governance Are Under Attack," The Chronicle of Higher Education, October 18, 2021, https://www.chronicle.com/newsletter/chroniclereview/2021-10-18.

9. Colleen Flaherty, "'What Cannot Be Tolerated,"' The Chronicle of Higher Education, September 14, 2021, https://www.insidehighered.com/news/2021/09/14/syracuse-offers-unequivocal-support-targeted-professor

10. https://www.nytimes.com/2021/11/12/opinion/book-bans.html.

11. Lindsay Ellis, " U. of Florida's Accreditor Will Investigate Denial of Professors' Voting-Rights Testimony," November 1, 2021, The Chronicle of Higher Education, https://www.chronicle.com/article/u-of-floridas-accreditorwill-investigate-denial-of-professors-voting-rights-testimony.

12. James Paterson, "Student Activism on the Rise," March 9, 2021, NEA Today, https://www.nea.org/advocatingfor-change/new-from-nea/student-activism-rise. 